\title{
Comparative study of five different squashes stored at room temperature
}

\author{
Hammad Wahab ${ }^{1}$, Sumayya Rani ${ }^{1 *}$, Uzma Shahni ${ }^{2}$, Abddul Sattar \\ Shah $^{1}$ and Beena Saeed ${ }^{3}$ \\ 1. Department of Agriculture (Food Science and Technology), The University of Swabi, Anbar Swabi-Pakistan \\ 2. Departmentof Health and Physical Education, Abdul Wali Khan University,Mardan-Pakistan \\ 3. Departmentof Agriculture (Agronomy),The Universityof Swabi, Anbar Swabi-Pakistan \\ *Corresponding author: Sumayya@uoswabi.edu.pk \\ Citation \\ Hammad Wahab, Sumayya Rani, Uzma Shahni, Abddul Sattar Shah and Beena Saeed. Comparative study of \\ five different squashes stored at room temperature. Pure and Applied Biology. Vol. 7, Issue 1, pp33-41.
} http://dx.doi.org/10.19045/bspab.2018.70005

\begin{tabular}{llll}
\hline \hline Received: 19/10/2017 & Revised: 22/12/2017 & Accepted: 25/12/2017 & Online First: 01/01/2018 \\
\hline
\end{tabular}

\section{Abstract}

The aim of the study was to prepare squash from different fruits and to investigate the effect of Potassium metabisulphite $(0.1 \%)$, storage time and temperature on the physiochemical and organoleptic properties of samples. During this study total five samples were prepared utilizing five different fruits which were peach, apple, guava, mango and lime such as $\mathrm{X}_{1}, \mathrm{X}_{2}, \mathrm{X}_{3}, \mathrm{X}_{4}$ and $\mathrm{X}_{5}$ and were preserved with $0.1 \%$ Potassium metabisulphite. The purpose of utilizing these fruits to prevent post-harvest loss in the peak season which is due to lack of proper post-harvest handling and preserving facility. These samples were randomly analyzed physiochemically $(\mathrm{pH}$, acidity, ascorbic acid content and total soluble solids) and organoleptically (taste, color and odor) with the storage interval of 15 days during one month storage. A decrease was observed in $\mathrm{pH}$ and ascorbic acid content while acidity and total soluble solids were found increased at $\alpha$ value less than 0.05 during storage. From this study it was concluded that $\mathrm{X}_{4}$ [ $(25 \%$ mango pulp $+25 \%$ distilled water $+50 \%$ Sugar + Citric acid $(0.75 \%)+0.1 \%$ Potassium metabisulphite $(0.075 \%)$ ] stayed very much acceptable as compared to others because of minimum changes in sensory evaluation score and physicochemical characteristics. Fruit based beverages are very important food products; further study is suggested on the refrigerated temperature to know the effect of temperature. Study on effect of other preservatives in different concentration is also recommended in future.

Keywords: Acidity; Ascorbic acid; Citric acid; Interval; pH; Sensory; Total soluble solids

\section{Introduction}

Squash is a beverage that is made from the combination of fruit pulp and sugar with the addition of water. Sugar is responsible for its sweet flavour [1]. Fruits and vegetables are good source of phytochemicals which are essential for many body functions many of them are antioxidants such as flavonoids and quercetin [2]. Peach (Prunus persica L.) is one among the four local fruits of China. It belongs to Northwest China between the Tarim Basin and the slopes of
Kunlun mountains, the place where it was first domesticated and cultivated [3]. According to statistics of FAO, in 2000 the total planting area of peach in China was 908000 hectares and the yield was 3830 000 tonnes. It is considered the leading country for peach production. In Northern areas of Pakistan peaches said to be the traditional crop where it occupies the area of 4543 hectares with the production of 48284 tonnes. Peach is an essential moneymaking fruit tree of Balochistan, with an 
area under cultivation of 60.22 hectares and production of 30.31 tonnes [4]. In respect to composition a medium peach contain 465 IU of vitamin A to compete the causing of aging and its $\beta$-carotene also helps to form a strong immune system to prohibit damage from free radicals, also to preclude many skin maladies [5]. Furthermore, peaches contain high amount of potassium, which is helpful for the maintenance of heart health and anticipation or regulation of high blood pressure[6]. Apple (Malus sylvestris) is one among well-known cultivated fruits. Production of apple throughout the World in 2008 was $64,255,520$ tonnes and China ranked first with production of 27,507,000 tonnes. The total area, reported under apple in Pakistan is about 45875 hectares with total production of 589281 tonnes (199899) per annum. It is mainly grown in hilly areas of Punjab, KPK and Balochistan. Important varieties are Kashmiri, Kandhari, Amri, Qalat Special, Golden delicious, Red delicious and Kulu. Apple also helps to handle dysentery [7]. Apple has the ability to stop the occurrence of Alzheimer's and Parkinson's diseases. Apart from these benefits, it also helps in dental care and skin care. The factors which affect the shelf-life of apple are the primary contamination by post-harvest pathogens and the condition in which it is kept. Due to their reasonable high metabolic activity, apple loss their quality during storage[8].They are collected over a limited period of time; that is why it is very important to arrange storage for the fruits to alter marketing and preserve high quality. Cold storage is mainly used to minimize the rate of respiration and ethylene production and also to increase the shelf-life of fruits. Long post-harvest life in cool storage is highly dependent on fruit quality [9]. Guava (Psidium guajava) family Myrtaceae is extensively grown all over the tropics and sub-tropics. Tropical America is the origin of guava but it has been in cultivation since early $17^{\text {th }}$ century in the sub-continent [10]. Depending on the species guava fruits are usually 4 to $12 \mathrm{~cm}$ (1.6 to 4.7 in) elongated, are round or oval [11]. This fruit is liked both in fresh and processed forms, which is the major cause of their production all over the world [12]. According to Sindh Board of Investment, Pakistan produces around 560,000 tonnes guava yearly with 58,500 hectares of land under its cultivation. Larkana district is the largest supplier in guava production accounting for $45 \%$ of Sindh's produce per year. Like other fruits and vegetables, Guava is also rich in antioxidants that aids in minimizing the occurrence of progressive abnormalities such as arthritis, arteriosclerosis, cancer, heart diseases, inflammation and brain dysfunction. Furthermore, antioxidants were described to delay ageing $[13,14]$ by inhibiting or deferring oxidative injury of lipids, proteins and nucleic acids. Guava leaves contain both carotenoids and polyphenols like (+)-gallocatechin and leucocyanidin [15].

Mango (Mangiferaindica L.) belongs to the family Anacadiacease, is known to be one of the main cultivated fruit throughout the world. The mango is inherent to South Asia [16] from where it has been circulated all over the world to become one of the most cultivated fruits in the tropics. Mangifera indica the "common mango" or "Indian mango" is the only mango tree generally cultivated in many tropical and subtropical areas [17].World production of mangoes was nearly 43 million tonnes in 2013, with India accounting for $42 \%$ (18 million tons) of the total. China and Thailand were the next leading producers. Mango is the second major fruit cultivated in Pakistan which covers 14 percent of the total area (734.6 thousand hectares). In Punjab, Multan and Bahawalpur divisions while Hyderabad and Mirpur Khas in Sindh are the leading mango growing districts in the country [18]. Mango is the most delicious fruit. It is liked not only due to its pleasant taste, aroma but also for its nutritional contribution to our diet. It is a vital source of energy and provides vitamins $\mathrm{A}, \mathrm{C}$ and minerals like iron and phosphorus. Juicy varieties of mango are favoured for 
manufacturing of squash. Squashes are sweetened juices containing some pulp. The term "cordial" is often used interchangeably with squash. Fruit squashes have a minimum of $25 \%$ by volume of a strong iron-rich diet with juicy mangoes [19]. Lime (Citrus aurantifolia) belongs to the family of Rutaceae and is grown almost in every home garden. Lime is a hybridized citrus fruit, which is usually round, lime green, 3-6 centimetres (1.2-2.4 in) in diameter, and having acidic juice vesicles. The total world production of lemons and limes was 15.42 million tonnes, with India top production of 2.52 million tonnes in 2013 [20]. Limes are brilliant source of vitamin $\mathrm{C}$, and are frequently used to improve the flavours of foods and beverages. They are grown year-round. Plants with fruit called "limes" have diverse genetic origins; limes do not form a monophyletic group [21]. From the nutrient database [22], raw lime contains $88 \%$ water, $10 \%$ carbohydrates and less than $1 \%$ each of fat and protein. Only vitamin $\mathrm{C}$ content at $35 \%$ of the Daily Value (DV) per $100 \mathrm{~g}$ serving is important for nourishment, with other nutrients existing in low DV amounts. Lime flesh and peel have diverse phytochemicals, containing polyphenols and terpenes [23] a lot of which are under basic research for their potential properties in humans [24]. The foremost coumarins in limes is limettin which has multiple higher content in peels than in pulp. Drinking lime juice with salt reduces the stomach pain. It helps in digestion of foods. Fruit juices and fruit juice beverages are becoming popular due to their pleasant flavour and nutritional characteristics. Beverages are consumed by people of all age group to quench the thirst as a social drink and for good health and medicinal values $[25,26]$.

In Pakistan peach, apple, guava, lime and mangoes are eaten in fresh form but during peak season when their production is high, post-harvest losses occur because of lacking proper handling and storage facilities. Keeping in view their nutritional significance and nutritionists suggestion to increase consumption of fruits and vegetables to decrease chances of obesity and cardiovascular diseases in population and to prevent post-harvest losses by product development, the present study was designed.

\section{Materials and methods}

Best quality fresh, mature and juicy fruits of peach, apple, guava, mango and lime were selected and bought from local fruit market of Peshawar and brought to Food processing lab of Nuclear Institute for Food and Agriculture Peshawar, KPK Pakistan. All the fruits were washed with water, after washing of fruits these fruits were peeled off and the seeds were been removed and then juice was extracted with the help of a juice extractor. The five samples were prepared by mixing the juice with sugar and distilled water in ratio of (2:2:4). Citric acid and Potassium metabisulphite was also added at the last. And were transferred to plastic bottles and kept at room temperature and labelled as $\mathrm{X}_{1}, \mathrm{X}_{2}, \mathrm{X}_{3}, \mathrm{X}_{4}$ and $\mathrm{X}_{5}$ (Table $1)$.

\section{Table 1. Proposed plan of study}

\begin{tabular}{|c|c|c|c|c|c|}
\hline Treatments & \% Juice & \%Water & \%Sugar & $\begin{array}{c}\text { \%Citric } \\
\text { Acid }\end{array}$ & $\begin{array}{c}\text { \%Potassium } \\
\text { Metabisulphite }\end{array}$ \\
\hline $\mathbf{X}_{\mathbf{1}}$ (Peach) & 25 & 25 & 50 & 0.75 & 0.075 \\
\hline $\mathbf{X}_{\mathbf{2}}$ (Apple) & 25 & 25 & 50 & 0.75 & 0.075 \\
\hline $\mathbf{X}_{\mathbf{3}}$ (Guava) & 25 & 25 & 50 & 0.75 & 0.075 \\
\hline $\mathbf{X}_{\mathbf{4}}$ (Mango) & 25 & 25 & 50 & 0.75 & 0.075 \\
\hline $\mathbf{X}_{\mathbf{5}}$ (Lime) & 25 & 25 & 50 & 0.75 & 0.075 \\
\hline
\end{tabular}

\section{Physicochemical analysis}

All sample were phsiochemically analyzed for different parameters by using the standard methods as described by [27] for $\mathrm{pH}$ values of all the samples were determined by method no 2005.02 for TSS 
by using a digital refractive meter, for Acidity using method no 920.183 and for Ascorbic Acid method no 920.183.

\section{Statistical analysis}

All the data regarding storage interval and treatments were statistically analyzed by CRD 2 factorial design as recommended by [29]. And the means were separated by applying least significant difference (LSD) test $5 \%$ probability level as defined by [30].

\section{Results and discussion}

\section{(\%) Acidity value of samples}

On first day Acidity value of all samples was calculated as $\mathrm{X}_{1}(1.23), \mathrm{X}_{2}(1.81), \mathrm{X}_{3}$ (1.92), $X_{4}$ (1.96) and $X_{5}(1.03)$ percent and on final day results were noted as $\mathrm{X}_{1}$ (1.44), $\mathrm{X}_{2}$ (2.01), $\mathrm{X}_{3}$ (2.12), $\mathrm{X}_{4}$ (2.16) and $\mathrm{X}_{5}$ (1.23) percent respectively. The average value was found increased from 1.59 to $1.79 \%$ at $\alpha$ value less than 0.05 . In samples highest percent increase was observed in $\mathrm{X}_{5}$ $(16.26 \%)$ second was $X_{1}(14.58 \%)$ and lowest increase in percent was observed in percent $\mathrm{X}_{4}(9.25 \%)$ next was $\mathrm{X}_{3}(9.43 \%)$ while highest mean value was noted in $\mathrm{X}_{4}$ (2.06) second by $\mathrm{X}_{3}$ (2.02) and lowest mean value was observed in $\mathrm{X}_{5}$ (1.13) next was $_{1}$ (1.33) (Table 2). It is clear from statistical analysis that storage time strongly affect all the sample equally. These results are in similarity with the findings of [31] who noticed the increasing trend of acidity in kinnow juice and with the findings of [32] during studies on fruit juices.

Table 2. Effect of storage on the \%acidity of different squashes

\begin{tabular}{|c|c|c|c|c|c|}
\hline \multirow{2}{*}{ Treatments } & \multicolumn{3}{|c|}{ Storage Interval } & \multirow{2}{*}{ \% Increase } & \multirow{2}{*}{ Mean } \\
\cline { 2 - 4 } & Initial & $\mathbf{1 5}$ & $\mathbf{3 0}$ & & \\
\hline $\mathrm{X}_{1}$ & 1.23 & 1.33 & 1.44 & 14.58 & $1.3300 \mathrm{~d}$ \\
\hline $\mathrm{X}_{2}$ & 1.81 & 1.91 & 2.01 & 9.95 & $1.9100 \mathrm{c}$ \\
\hline $\mathrm{X}_{3}$ & 1.92 & 2.02 & 2.12 & 9.43 & $2.0200 \mathrm{~b}$ \\
\hline $\mathrm{X}_{4}$ & 1.96 & 2.06 & 2.16 & 9.25 & $2.0600 \mathrm{a}$ \\
\hline $\mathrm{X}_{5}$ & 1.03 & 1.13 & 1.23 & 16.26 & $1.1300 \mathrm{e}$ \\
\hline Mean & $1.59 \mathrm{c}$ & $1.69 \mathrm{~b}$ & $1.792 \mathrm{a}$ & & \\
\hline
\end{tabular}

\section{Ascorbic Acid (mg/100g) content of samples}

On first day Ascorbic acid value of all samples was calculated as $\mathrm{X}_{1}(26.19), \mathrm{X}_{2}$ (20.37), $X_{3}$ (33.46), $X_{4}(36.37)$ and $X_{5}$ (23.28) percent and on final day results were noted as $\mathrm{X}_{1}(25.99), \mathrm{X}_{2}(20.17), \mathrm{X}_{3}$ (33.26), $X_{4}(36.17)$ and $X_{5}(23.07)$ percent respectively. The average value was found decreased from 27.93 to $27.72 \%$ at $\alpha$ value less than 0.05 . In samples highest percent decrease was observed in $\mathrm{X}_{5}(0.90 \%)$ second was $\mathrm{X}_{1}(0.76 \%)$ and lowest decrease in percent was observed in percent $\mathrm{X}_{4}(0.54 \%)$ next was $\mathrm{X}_{3}(0.59 \%)$ while highest mean value was noted in $\mathrm{X}_{4}$ (36.270) second by $\mathrm{X}_{3}$ (33.360) and lowest mean value was observed in $\mathrm{X}_{2}$ (20.27) next was $\mathrm{X}_{5}$ (23.17) (Table 3). It is clear from statistical analysis that storage time strongly affect all the sample equally.
These results are in similarity with the findings of [33] while working on mango leather. The results achieved in the work of [34] also showed decrease in ascorbic acid content. And stated that decrease in ascorbic acid content is due to presence of oxygen product and other cause is head space in the product packaging.

\section{pH value of samples}

On first day $\mathrm{pH}$ value of all samples was calculated as $\mathrm{X}_{1}(3.61), \mathrm{X}_{2}(3.75), \mathrm{X}_{3}$ (3.68), $\mathrm{X}_{4}(3.81)$ and $\mathrm{X}_{5}$ (3.63) percent and on final day results were noted as $X_{1}$ (3.57), $X_{2}$ (3.65), $\mathrm{X}_{3}$ (3.61), $\mathrm{X}_{4}$ (3.76) and $\mathrm{X}_{5}$ (3.40) percent respectively. The average value was found decreased from 3.69 to $3.59 \%$ at $\alpha$ value less than 0.05 . In samples highest percent decrease was observed in $\mathrm{X}_{2}$ $(2.78 \%)$ second was $\mathrm{X}_{2}(2.66 \%)$ and lowest decrease in percent was observed in $\mathrm{X}_{1}$ $(1.10 \%)$ next was $\mathrm{X}_{4}(1.31 \%)$ while highest 
mean value was noted in $\mathrm{X}_{4}$ (3.78) second by $\mathrm{X}_{2}$ (3.71) and lowest mean value was observed in $\mathrm{X}_{5}(3.51)$ next was $\mathrm{X}_{1}(3.58)$ (Table 4). It is clear from statistical analysis that storage time strongly affect all the sample equally. These results are in similarity with the findings of [35] who observed a decrease in $\mathrm{pH}$ of ready to serve mandarin drink.

Table 3. Effect of storage on the ascorbic acid content of different squashes

\begin{tabular}{|c|c|c|c|c|c|}
\hline \multirow{2}{*}{ Treatments } & \multicolumn{3}{|c|}{ Storage Interval } & \multirow{2}{*}{ \%Decrease } & \multirow{2}{*}{ Mean } \\
\cline { 2 - 4 } & Initial & $\mathbf{1 5}$ & $\mathbf{3 0}$ & & \\
\hline $\mathrm{X}_{1}$ & 26.19 & 26.09 & 25.99 & 0.76 & $26.090 \mathrm{c}$ \\
\hline $\mathrm{X}_{2}$ & 20.37 & 20.27 & 20.17 & 0.98 & $20.270 \mathrm{e}$ \\
\hline $\mathrm{X}_{3}$ & 33.46 & 33.36 & 33.26 & 0.59 & $33.360 \mathrm{~b}$ \\
\hline $\mathrm{X}_{4}$ & 36.37 & 36.27 & 36.17 & 0.54 & $36.270 \mathrm{a}$ \\
\hline $\mathrm{X}_{5}$ & 23.28 & 23.17 & 23.07 & 0.90 & $23.173 \mathrm{~d}$ \\
\hline Mean & $27.934 \mathrm{a}$ & $27.832 \mathrm{~b}$ & $27.723 \mathrm{c}$ & & \\
\hline
\end{tabular}

Table 4. Effect of storage on the pH of different squashes

\begin{tabular}{|c|c|c|c|c|c|}
\hline \multirow{2}{*}{ Treatments } & \multicolumn{3}{|c|}{ Storage Interval } & \multirow{2}{*}{ \% Decrease } & \multirow{2}{*}{ Mean } \\
\cline { 2 - 4 } & Initial & $\mathbf{1 5}$ & $\mathbf{3 0}$ & & \\
\hline $\mathrm{X}_{1}$ & 3.61 & 3.58 & 3.57 & 1.10 & $3.5867 \mathrm{~cd}$ \\
\hline $\mathrm{X}_{2}$ & 3.75 & 3.72 & 3.65 & 2.66 & $3.7100 \mathrm{~b}$ \\
\hline $\mathrm{X}_{3}$ & 3.68 & 3.66 & 3.61 & 1.90 & $3.6500 \mathrm{bc}$ \\
\hline $\mathrm{X}_{4}$ & 3.81 & 3.79 & 3.76 & 1.31 & $3.7867 \mathrm{a}$ \\
\hline $\mathrm{X}_{5}$ & 3.63 & 3.51 & 3.40 & 2.78 & $3.5133 \mathrm{~d}$ \\
\hline Mean & $3.6880 \mathrm{a}$ & $3.6540 \mathrm{ab}$ & $3.5980 \mathrm{~b}$ & & \\
\hline
\end{tabular}

Total soluble solids $\left({ }^{\circ}\right.$ brix) of samples

On first day Ascorbic acid value of all samples was calculated as $\mathrm{X}_{1}(54), \mathrm{X}_{2}(58)$, $\mathrm{X}_{3}(50), \mathrm{X}_{4}(53)$ and $\mathrm{X}_{5}(53){ }^{\circ}$ brix and on final day results were noted as $X_{1}(60), X_{2}$ (60), $X_{3}$ (53), $X_{4}(54)$ and $X_{5}$ (56) and degree ${ }^{\circ}$ brix respectively. The average value was found decreased from 53.6 to $56.80^{\circ}$ brix respectively at $\alpha$ value less than 0.05 . In samples highest percent decrease was observed in $\mathrm{X}_{1}(10 \%)$ second was $\mathrm{X}_{3}$
(7.40\%) and lowest decrease in percent was observed in percent $\mathrm{X}_{4}(1.88 \%)$ next was $\mathrm{X}_{2}$ $(3.33 \%)$ (Table no. 04) while highest mean value was noted in $X_{2}$ (59) second by $\mathrm{X}_{1}(57)$ and lowest mean value was observed in $X_{3}(52)$ next was $X_{4}$ (53.33) (Table 5). It is clear from statistical analysis that storage time strongly affect all the sample equally. These results are in similarity with the findings of [36] in their studies on lime juice.

Table 5. Effect of storage on the total soluble solids of different squashes

\begin{tabular}{|c|c|c|c|c|c|}
\hline \multirow{2}{*}{ Treatments } & \multicolumn{3}{|c|}{ Storage Interval } & \multirow{2}{*}{ \% Increase } & \multirow{2}{*}{ Mean } \\
\cline { 2 - 4 } & Initial & $\mathbf{1 5}$ & $\mathbf{3 0}$ & & \\
\hline $\mathrm{X}_{1}$ & 54 & 57 & 60 & 10.0 & $57.00 \mathrm{~b}$ \\
\hline $\mathrm{X}_{2}$ & 58 & 59 & 60 & 3.33 & $59.00 \mathrm{a}$ \\
\hline $\mathrm{X}_{3}$ & 50 & 52 & 54 & 7.40 & $52.00 \mathrm{~d}$ \\
\hline $\mathrm{X}_{4}$ & 53 & 53 & 54 & 1.88 & $53.33 \mathrm{~cd}$ \\
\hline $\mathrm{X}_{5}$ & 53 & 56 & 56 & 5.35 & $55.00 \mathrm{c}$ \\
\hline Mean & $53.60 \mathrm{~b}$ & $55.40 \mathrm{a}$ & $56.80 \mathrm{a}$ & & \\
\hline
\end{tabular}


Color score of samples

On the first day judges score for color of all samples was calculated as $\mathrm{X}_{1}(8.0), \mathrm{X}_{2}$ (7.6), $\mathrm{X}_{3}$ (7.3), $\mathrm{X}_{4}$ (9.0) and $\mathrm{X}_{5}$ (6.5) percent and on final day results were noted as $\mathrm{X}_{1}$ (7.5), $\mathrm{X}_{2}$ (7.0), $\mathrm{X}_{3}(6.5), \mathrm{X}_{4}(8.5)$ and $\mathrm{X}_{5}$ (6.0) percent respectively. The average value was found decreased from7.68 to $7.10 \%$ at $\alpha$ value less than 0.05 . In samples highest mean score of judges was observed in $\mathrm{X}_{4}(8.73 \%)$ second was $\mathrm{X}_{1}(7.83 \%)$ and lowest decrease in mean score of judges was observed in $\mathrm{X}_{5}(6.30 \%)$ next was X3 $(6.93 \%)$ (Table 6). It is clear from statistical analysis that storage time strongly affect all the sample equally. These results are in similarity with the findings of [37] they observed a gradual decrease in score of judges for color in Jamun squash, in Chinese orange squash by [38].

Table 6. Effect of storage on the color of different squashes

\begin{tabular}{|c|c|c|c|c|}
\hline \multirow{2}{*}{ Treatments } & \multicolumn{3}{|c|}{ Storage Interval } & \multirow{2}{*}{ Mean } \\
\cline { 2 - 4 } & Initial & $\mathbf{1 5}$ & $\mathbf{3 0}$ & $7.83 \mathrm{~b}$ \\
\hline $\mathrm{X}_{1}$ & 8 & 8 & 7.5 & $7.3 \mathrm{c}$ \\
\hline $\mathrm{X}_{2}$ & 7.6 & 7.3 & 7 & $6.93 \mathrm{~d}$ \\
\hline $\mathrm{X}_{3}$ & 7.3 & 7 & 6.5 & $8.73 \mathrm{a}$ \\
\hline $\mathrm{X}_{4}$ & 9 & 8.7 & 8.5 & $6.30 \mathrm{e}$ \\
\hline $\mathrm{X}_{5}$ & 6.5 & 6.5 & 6 & \\
\hline Mean & $7.68 \mathrm{a}$ & $7.50 \mathrm{~b}$ & $7.10 \mathrm{c}$ & \\
\hline
\end{tabular}

\section{Odour score of samples}

On first day judges score for odour all samples was calculated as $\mathrm{X}_{1}(8.7), \mathrm{X}_{2}$ (8.0), $\mathrm{X}_{3}$ (8.5), $\mathrm{X}_{4}(9.0)$ and $\mathrm{X}_{5}$ (6.5) percent and on final day results were noted as $X_{1}(7.0), X_{2}(6.5), X_{3}(5.7), X_{4}(8.0)$ and $\mathrm{X}_{5}$ (2.00) percent respectively. The average value was found decreased from 8.14 to $6.90 \%$ at $\alpha$ value less than 0.05 . Maximum mean score of judges for flavor was obtained by $\mathrm{X}_{4}$ (8.50) followed by $\mathrm{X}_{1}$ (7.73) and minimum mean score was obtained $\mathrm{X}_{5}$ (6.16) next was $\mathrm{X}_{2}$ (7.16).
Maximum decrease in judges score was found in $\mathrm{X}_{1}$ (19.54) and next was $\mathrm{X}_{2}(18.75)$ and minimum decrease was found in $\mathrm{X}_{5}$ (7.69) and next was $\mathrm{X}_{4}(11.11)$ (Table 7). It is clear from statistical analysis that storage time strongly affect all the samples equally. These results are in similarity with the findings of [39] who during his work on Vitamin $\mathrm{C}$ enrichment of fruit juice and [40] also reported the declining in scores in the stored juice product because of production of off flavor substances.

Table 7. Effect of storage on the odor of different squashes

\begin{tabular}{|c|c|c|c|c|}
\hline \multirow{2}{*}{ Treatments } & \multicolumn{3}{|c|}{ Storage Interval } & \multirow{2}{*}{ Mean } \\
\cline { 2 - 4 } & Initial & $\mathbf{1 5}$ & $\mathbf{3 0}$ & $7.73 \mathrm{~b}$ \\
\hline $\mathrm{X}_{1}$ & 8.7 & 7.5 & 7 & $7.16 \mathrm{c}$ \\
\hline $\mathrm{X}_{2}$ & 8 & 7 & 6.5 & $7.66 \mathrm{bc}$ \\
\hline $\mathrm{X}_{3}$ & 8.5 & 7.5 & 7 & $8.5 \mathrm{a}$ \\
\hline $\mathrm{X}_{4}$ & 9 & 8.5 & 8 & $6.16 \mathrm{~d}$ \\
\hline $\mathrm{X}_{5}$ & 6.5 & 6 & 6 & \\
\hline Mean & $8.14 \mathrm{a}$ & $7.30 \mathrm{~b}$ & $6.90 \mathrm{c}$ & \\
\hline
\end{tabular}

\section{Taste score of samples}

On first day judges score for tase value of all samples was calculated as $\mathrm{X}_{1}(8.0), \mathrm{X}_{2}$ (7.5), $X_{3}$ (7.0), $X_{4}$ (9.0) and $X_{5}(8.0)$ percent and on final day results were noted as $X_{1}$ (7.3), $X_{2}$ (6.5), $X_{3}$ (6.0), $X_{4}(8.5)$ and $\mathrm{X}_{5}$ (6.5) percent respectively. The average value was found decreased from 7.90 to 
$6.96 \%$ at $\alpha$ value less than 0.05 . Highest mean value was noted in $\mathrm{X}_{4}$ (8.66) second was $X_{1}$ (7.6) and lowest mean value was observed in $\mathrm{X}_{3}$ (6.66) next was $\mathrm{X}_{2}$ (7.0) (Table 8). It is clear from statistical analysis that storage time strongly affect all the sample equally. These results are in similarity with the findings of [41] while their work one effect of sugar levels and storage period of physiochemical and sensory characteristics of Chinese orange squash [42] reported that during the storage time and temperature taste of the product is adversely affected while studying the physiochemical and sensory properties of orange.

Table 8. Effect of storage on the taste of different squashes

\begin{tabular}{|c|c|c|c|c|}
\hline \multirow{2}{*}{ Treatments } & \multicolumn{3}{|c|}{ Storage Interval } & \multirow{2}{*}{ Mean } \\
\cline { 2 - 4 } & Initial & $\mathbf{1 5}$ & $\mathbf{3 0}$ & $7.6 \mathrm{~b}$ \\
\hline $\mathrm{X}_{1}$ & 8 & 7.5 & 7.3 & $7 \mathrm{~cd}$ \\
\hline $\mathrm{X}_{2}$ & 7.5 & 7 & 6.5 & $6.66 \mathrm{bc}$ \\
\hline $\mathrm{X}_{3}$ & 7 & 7 & 6 & $8.66 \mathrm{a}$ \\
\hline $\mathrm{X}_{4}$ & 9 & 8.5 & 8.5 & $7.3 \mathrm{bc}$ \\
\hline $\mathrm{X}_{5}$ & 8 & 7.5 & 6.5 & \\
\hline Mean & $7.9 \mathrm{a}$ & $7.5 \mathrm{~b}$ & $6.96 \mathrm{c}$ & \\
\hline
\end{tabular}

\section{Conclusions and recommendations}

From this study it was concluded that the potassium metabisulphite alongwith citric acid and sugars has strong effect on the overall quality of mango squash. It was concludedthat $\mathrm{X}_{4}(25 \%$ mango pulp $+25 \%$ distilled water $+50 \%$ Sugar + Citric acid $(0.75 \%)+0.1 \%$ Potassium Meta-Bisulphite stayed very much acceptable during 30 days of storage. In future the same study is recommended at low temperature. Moreover microbial evaluation is also recommended. Packaging influence on the product quality is also suggested to study in future. Study on effect of other preservatives in different concentration is also recommended in future.

\section{Authors' contributions}

Conceived and designed the experiments: $\mathrm{S}$ Rani, Performed the experiments: H Wahab \& U Shahni, Analyzed the data: H Wahab \& AS Shah, Contributed materials/ analysis/ tools: B Saeed, H Wahab \& U Shahni, Wrote the paper: S Rani \& H Wahab

\section{Acknowledgement}

Im very thankful to NIFA Peshawar for providing us research facilities and technical guidance.

\section{References}

1. Ahmad M C \& Khan MA (1986). Technological studies on citrus and other fruit based drinks. Nucleus 23(34): 41-45.

2. Mehmood Z, Zeb A, Ayub M, Bibi N, Badshah A, Ullah I (2008). Effect of pasteurization and chemical preservation on the quality and shelf stability of apple juice. Amer J of Food Tech 3(2): 147-153.

3. Faust M \& Timon BL (2010). Origin and Dissemination of Peach. Horticultural Reviews 331.

4. Wasim (2011). Administration of misoprostol by trained traditional birth attendants to prevent postpartum haemorrhage in homebirths in Pakistan: a randomized place bocontrolled trial. An International Journal of Obstetrics \& Gynaecology 118(3): 353-361.

5. Terry CW, Anthony JC, Joseph PC, Rachael MC\& Daniel CC (1996-2008). The perfect peach fruit's benefits. Miami (Florida).

6. Crociani F, Alessandrini A, \& Mucci MM (2001). Prunuspersica is native to China. USDA National nutrient database for standard reference: Technomic Publishing Co Inc 125-128. 
7. Chaudar MI (1994). Fruit crops: Int Hort. 17th Ed. National book foundation; Islamabad $468 \mathrm{p}$.

8. Kazemi M, Aran M, \& Zamani S (2011). Effect of salicylic acid treatments on quality characteristics of apple fruits during storage. Aerican Journal of Plant Physioogyl 6 (2): 113-119.

9. Omaima M \& Haggag HE (2007).Quality improvement and storability of apple cvanna by preharvest applications of boric acid and calcium chloride. Researh Journal of Agriculture 4(4): 225-228.

10. Fattahi J, Fifall R \& Babri M (2010). Postharvest quality of kiwifruit (Actinidiadeliciosa ca hayward) Affected by pre storage application of salicylic acid. South western Journal of Horticulture, Biology \& environment 1(2): 175-186.

11. Mitra RJ \&Bose TK (1990).Guava In: Fruits tropical and sub-tropical. Eds. Nayaprokash Calcutta (India) 6: 280303.

12. Morton J (1987). Mango Fruits of warm climates. New Crop Resource Online Program, Center for New Crops \& Plant Products, Purdue University, 221-239.

13. Amorim D, Souza HAD, Rozane DE, Montes R \& Natale W (2015). Nitrogen and potassium fertilization in Palumaguava trees: Effect on nutritional status of the plants. Revista Brasileira de Fruticultura 37(1): 210219.

14. Feskanich D, Ziegler RG, Michaud DS, Giovannucci EL, Speizer FE, Willett WC \& Colditz GA (2000). Prospective study of fruit and vegetable consumption and risk of lung cancer among men and women. Journal of the National Cancer Institute 92: 1812-1823.

15. Halliwell B (1996). Antioxidants in human health and disease. Ann Rev Nutr 16: 33-50.

16. Seshadri TR \&Vasishta K. (1965).Polyphenols of the leaves of psidiumguavaquercetin, guaijaverin, leucocyanidin and amritoside. Phyto chemistry 4(6): 989-992.

17. Morton J (1987).MangoFruits of warm climates.New Crop Resource Online Program Center for New Crops \& Plant Products Purdue University 221-239.

18. Kostermans AJHG \&Bompard JM (1993). The Mangoes: Their Botany, Nomenclature, Horticulture and Utilization. Academic Press.

19. Govt. of Pak (2004). Agricultural statistics of Pakistan. Ministry of Food, Agric. And Livestock Econ Wing Islamabad.

20. Food and Agricultural Organization (2006). Production Year Book, Food and Agricultural Organization Rome (Italy). Production/Crops/World for lemons and limes.

21. Food and Agricultural Organization of United Nations Statistics Division (2013). Production/Crops/World for lemons and limes.

22. United States Department of Agriculture Agricultural Research Service (2000).Nutrient database for Standard Reference, 13p.

23. Rotter B (2014). Fruit Data: Yield, Sugar, Acidity, Tannin at Improved Winemaking.www.brsquared.org/win e.

24. Loizzo MR, Tundis R, Bonesi M, Menichini F, Luca D, Colica, C, \& Menichini F (2012). Evaluation of Citrus aurantifolia peel and leaves extracts for their chemical composition, antioxidant and anticholinesterase activities. Journal of the Science of Food and Agriculture 92(15): 2960-2967.

25. Patil JR, Murthy CKN, Jayaprakasha GK, Chetti MB \& Patil BS (2009). Bioactive compounds from Mexican lime (Citrus aurantifolia) juice induce apoptosis in human pancreatic cells. Journal of A gricultural and Food Chemistry 57(22): 10933-10942.

26. Nigg HN, Nordby HE, Beier RC, Dillman A, Macias C \& Hansen RC 
(1993). Photo toxic coumarins in limes. Food Chem Toxicol 31(5): 3315.

27. AOAC (2000). Official Methods of Analysis. 17th Ed.The Association of the official Analytical Chemists. Arlingto 17p.

28. Larmond E (1977). Laboratory methods for sensory evaluation of food: Research branch, Canada dept of Agriculture.

29. Gomez KA \& Gomez AA (1984). Statistical procedures for agricultural research. John Wiley \& Sons.

30. Steel RG \& Torrie JH (1980). Analysis of covariance. Principles and procedures of statistics: A Biometrical Approach 401-437.

31. Sandhu KS \& Singh S (2001). Studies on the factors affecting the physicochemical and organoleptic of kinnow juice. J Food Sci \& Tech 8(3): 266-269.

32. Rodriqo D, Arranz JI, Koch S, Frigola A, Rodriqo MC, Esteve MJ, Calvo C \& Radriqo M (2003). Physiochemical characteristic and quality of refrigerated Spanish orange-carrot juices and influence of storage conditions. J Food Sci 68(6): 21112116.

33. Azerdo HMC, Brito ES, Moreira GEG, Farias VL, Bruno LM (2000). Effect of drying and storage time on the physiochemical prpoerties of mango leather. Int J of Food Sci Tech 41:635638.

34. Wisal S, Ullah J, Zeb A, Khan MZ (2008).Effect of refrigeration temperature, sugar concentrations and different chemical preservatives on the storage stability of strawberry juice. Int J Engg Tech 3: 160-168.

35. Mehmood Z, Zeb A, Ayub M, Bibi N, Badshah A \& Ullah I (2008). Effect of pasteurization and chemical preservatives on the quality and shelf life stability of apple juice. J Food Tech 3(2): 147-153.

36. Ahmed M, Ahmad A, Chatha ZA \& Dilshad SMR (2008). Studies on preparation of ready to serve mandarin (Citrus reticulata) diet drink. Pak J Agri Sci 45(4): 470-476.

37. Pandey AK (2004). Study about the storage stability of guava beverages. Progressive Horticulture 36(1): 142145.

38. Kaman S \& Thirumaran S (2001). Studies on storage life of jamun products. Indian Food Packer 25: $125-$ 127.

39. Jain SK \&Khurdiya DS (2004). Vitamin C enrichment of fruit juice based ready to serve beverages through blending of Indian gooseberry (Emblicaofficianlis gaertn) juice. Plant Foods for human nutrition 59: 63-66.

40. Bezman Y, Russel R \& Naim M (2001). 2-Methyl-3-furanthiol and methional are possible off-flavors in stored juice. J Agric Food Chem 49(5): 425-432.

41. Tiwari M, Khan A, \& Srivastava PK (2010). Effect of sugar levels and storage period of physic-chemical and sensory characteristics of Chinese orange squash. Beverage \& Food World 5: 37-39.

42. Jain S, Sankhla APK, Dashora A \&Sankhla AK (2003). Physiochemical and sensory properties of orange drink. J Food Sci Tech India 40(6): 656-659. 